\title{
XXIII. On meteorological nomenclature
}

\section{P.J. Brown Esq.}

To cite this article: P.J. Brown Esq. (1816) XXIII. On meteorological nomenclature, Philosophical Magazine Series 1, 47:214, 107-109, DOI: 10.1080/14786441608638808

To link to this article: http://dx.doi.org/10.1080/14786441608638808

曲 Published online: 27 Jul 2009.

Submit your article to this journal $2 \pi$

Џ Article views: 2

Q View related articles $₫$ 
the arc $47^{\circ} 20^{\prime}$, while M. LAPLACE's Elements are $\cdot 01469$ and $46^{\circ} 48^{\prime}$.

\begin{tabular}{|c|c|c|c|c|c|c|c|}
\hline \multirow[t]{2}{*}{ Diam. } & \multicolumn{2}{|c|}{ Depression. } & \multirow{3}{*}{$\begin{array}{l}\text { ID.C.C. } \\
1776 .\end{array}$} & Diatn. & \multicolumn{2}{|c|}{ Depression. } & \multirow[b]{2}{*}{$\mathrm{I}^{\mathrm{D}}$. C. C. } \\
\hline & No: Crr. & LAPL. & & & NrCT. & LAPL. & \\
\hline - 8 & $\begin{array}{r}180 \\
.001\end{array}$ & & & $\cdot 3$ & & & $17 i 6$. \\
\hline .7 & .00 & .00 & & 23 & .04 & $\cdot 0$ & .05 \\
\hline .6 & .00416 & .00462 & .005 & $\cdot 2$ & .05502 & .05 & .067 \\
\hline .5 & $\cdot 00805$ & .00868 & .007 & $\cdot 15$ & $\cdot 08$ & $\cdot 0 s$ & $\cdot 0.92$ \\
\hline$\cdot 15$ & .01 & .01 & & $\cdot 1$ & -14027 & .01394 & $\cdot 140$ \\
\hline$\cdot 4$ & .01522 & .01591 & .01 & .05 & $\cdot 29497$ & & \\
\hline .35 & $.0209 S$ & .02165 & .02 & & & & \\
\hline
\end{tabular}

A. B. C. D.]

XXIII. On Meteorological Nomenclature. By P. J. Brows, Esq.

To Mr. Tilloch.

Sir, - $W_{\text {ANT }}$ of leisure has prevented my perusing, till this evening, Mr. Forster's paper on the nomenclature of clouds published in your last number, and I regret being compelled to differ in opinion from a person for whose talents $I$ have so much respect. In every clepartment of polite literature, with the exception of scientific nomenclature, I feel decidedly hostile to the late fashionable introduction of exotic words*: the writings of Swift, whose language must be admired by cvery lover of pure English, have fully proved the adequacy of our mother tongue, for every purpose of general composition: but it should be recollected, in adopting scientific terms, that science is not a native of any particular country; but a citizen of the world who will always be protected and fostered in every state alive to its own interest and glory: it is consequently evident that the language of science should be, to as great an extent as can be accomplished, intelligible to all.

Consider the state of chemical knowledge when the illustrious Lavoisier composed his excellent nomenclature: can it be supposed that the acquisition of that most pleasing and useful science would have become so general, if, instead of adopting

* Addison's excellent and humouruus paper in the Spcctator, No. 105, is as applicable to the present day, ns it could possibly have been to the time of the battle of Blenheim: low many dispatches during the late war would have left half London ipnorant of the fite of a battle, lad not the guns told them in more intelligible terms that our brave countrymen had gained the victory! 
terms casy to be comprehended by all persons of moderate edifcation, he had runmased tie old ne a set of uncouth epithes w lich would have fosed an anliquary? Suppose that the sill move illurions Limoris, insteac of his most admirible, comprehensive, and comprehensille terms, had pub-

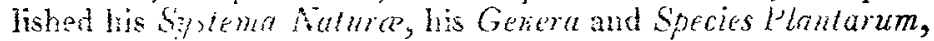
with a scinific nomedature extracted from the barbarcus radicals of he swetion hugnage, can it be for a moment thought that the study of nature, and consequent expansion of the human mind, would have been so universal is it happily has been?

In illustration, let us consider the languages of botany and miveralogy: a person possessing no more knowledge of the leartied languages than is vecessity for the proper conprehending of onr own, whthout being able to translate a single line of Virgil or llorace, miy fiom the nuiversil adoption of the Linnaan phrseolowy in a resy short time be able to take up the Fora of aimost auy country, and siroll with jts anthor through paths of fowers; now invesigating the seanty berbage of the northem regions, ant then reseling in the magnificent productions of Nes. Holland or the Cape. Mineralogy on the contrary, whose convexion with chemistry, whose curable productions abounding with beaty, briliany, and the nost correct geometry, would, under more faromable ciremstances, have been studied with delight, is comparatirely neglected; and may not the neglert be ia a gleat measure attributed to the jargon with which it is incumbered? a jargon unintelligible to any but the Germans, from whom it sprung, and the few who have degraded themselves by their conversion into Germanised Englishmen! Had the state of chemical and mineralogical knowledge been the same in the tine of Limneus as it is at present, he would most probably have occisend the extensive cultivation of the latter, by hestowing on it a !nguge brilinnt and exact as its own native crystals; whereas tlie student is now enveloped in a fog, dark and impenetrable as the recosses from whence those crystals are de$1 \mathrm{i} y+\mathrm{d}_{2}$

IX. Forster's meteorolngicnl observations were intended fic the information of his countrymen only, and wers made $k$ nown to fliem through a medium the circulation of wich was confined to the limits of ou own iste, there cond be no objection to lis conveying instruction in the terms he proposes; but whet it is recollected that your valuable Magazine most deservediy attrats the attention of those citizens of the scientific commonweulth who reside abroad*; I should hope thas, on reconsifering

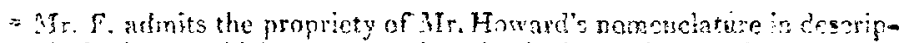

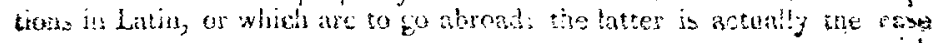


the circumstance, it will appear to him as unadrisable to force a set of saxon terms upon our fellow-labouress on the continent; as it would be in ourselves to injure our masticating apparatus, by incfectnally conlearcuring to become masters of the German mineralogical disconancet.

I by no means wish this to be concidered as the commencement of a controversy, bat as containing a siatement of the opinion of one whose want of knowledge is, perhaps, only equalled by his regret that his knowledge is not more extended.

$I$ have the honour to be, sir,

Your most obedient humble servant,

Old Brompton, Feb. 12, 1816.

P. J. Brown.

P.S.-The snapping of sulphur when held in the warm hand, as noticed by your correspondent $J$. F., is a property which has long been known: it is mentioned by several authors to whose works I have not the opportunity of immediate reference; but I can venture from memory to refer to the lesson on Sulphur in Lagrange's Mantual of Chemistry: for J. F's ingenious observations on the subject he has full credit.

with those inserted in your Magazine: and with respect to the dificulty of impressing on the minds of mere English readers, names derived from the Latin, it is presumed that the term cumulus will as readily convey the idea of a beaping up, or accumulation (ad cumulus) of clouds, as the proposed one of stackeneloud: indeed, if new terms must be acquired, the trifling additional dificulty (should any exist) will be no inipedinent to those stimulated by a desire to learn.

+ As many of your young readers wha are pleased with the study of mineralogy may not have entered into its investigations five years ago, I shall consider no ajollogy necossary for recommending to their perusal Mr. Chenerix"s "Reflections on some Mineralogical Systems," published in your $x \times x$ ith and following volumes. In volume $x \times x$ vith, arin last paragraph of page 379 , I would suggest a manuscript reference to be made to vol. xlii. page 25, where Professor Stromeyer's Observations on the Cormposition of Arragonite will add force to Mr. C.'s arguments; by removing the only oljection of any weight which remained opposed to the systena of M. Haïy. Newton incurred the ridicule of the psendo-philosophers of his dav, ty arguing from therry, that diamond ought to be inflammable, and that ratce itself should also contain much infanmable matter. Those whose ridicule he experienced harl long rested in their graves, when the brilliant discoveries of modern chemistly proved the correctuess of his assertion. Can M. Ialiy's principles need a more honourable comparison? They pointed out to him that arragonite ought to differ from carbonate of lime; the most celehrated chemists of the early part of the 19th century were long unithe to detect the difference; it is at length discovered, to the immortal honour of the French philosopher, and I trust to the sad discon. fiture of the partisans of erternal characters and mineralngical instinct. 